\begin{tabular}{lc}
\hline CURRENT & ISSN: 0973-4929, Vol. 13, (Special Issue 1) 2018, Pg. 01-03 \\
WORLD & Current World Environment \\
& Journal Website: www.cwejournal.org \\
\hline
\end{tabular}

\title{
Planning Greenspace for the Highlands Region of Surabaya
}

\section{ARDYTTO ISTIANTO and SARWOKO MANGKOEDIHARDJO*}

Department of Environmental Engineering, Institut Teknologi

Sepuluh Nopember (ITS), Surabaya, Indonesia.

\begin{abstract}
This paper reports the evaluation and planning of greenspace in the highlands region of Surabaya. Evaluation was conducted by taking primary data related to the number of vehicles with traffic counting method and secondary data in the form of population, vegetation type, and pattern of greenspace vegetation planting. The calculation of the adequacy of greenspace was done by calculating the volume of carbon dioxide emissions by humans and vehicles. The calculation was then multiplied by the emission factor. This helped in calculating the absorption capacity of total carbon dioxide from the existing greenspace vegetation. The results showed that the existing vegetation could be preserved and enriched with the addition of vegetation species to absorb carbon dioxide gas emissions and in accordance with the existing laws and regulations.
\end{abstract}

\section{Introduction}

The increasing number of population and economic activity leads to higher activity that produces air pollution such as industry and transportation as well as other environmental problems. One effort to overcome environmental problems is with the provision of greenspace to absorb carbon dioxide. Urban greenspace basically has the main function of supporting sustainability of urban life, so that the existence of greenspace in urban area is a requirement that must be fulfilled for healthy society life. ${ }^{1}$ Minimum greenspace area of a city that is at least $30 \%$ of the total area. $^{2}$ Surabaya has a new greenspace of $21 \%$ of the total area. The city of Surabaya has an area that is a plateau of $19.28 \%$ of the city area. ${ }^{3}$ The highlands should have the widest greenspace and decline in line with the territory slope. Reforestation in the highlands can maximize the input of rainwater into the soil. The effect of greenspace expansion on the plateau not only ensures the availability of ground water but also reduces downstream flooding. ${ }^{4}$

CONTACT Sarwoko Mangkoedihardjo $\$$ prosarwoko@gmail.com 9 Department of Environmental Engineering, Institut Teknologi Sepuluh Nopember (ITS), Surabaya, Indonesia.

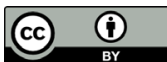

(c) 2018 The Author(s). Published by Enviro Research Publishers.

This is an 6 Open Access article licensed under a Creative Commons license: Attribution 4.0 International (CC-BY).

Doi: 10.12944/CWE.13.Special-Issue1.01 


\section{Methods}

Planning zone included public open space with a height of 20 mean sea level and more as define here as highlands region. Data collection included primary data. This was collected by counting the number of vehicles at 06.00-08.00 am and 16.00-18.00 pm on workdays during February to March, 2018. Vehicles counted included 2 and 4-wheeled motor vehicles. In addition to this, secondary data was also collected, which included road network map, elevation area, and existing vegetation.

The calculation of the adequacy of greenspace was done by calculating the volume of carbon dioxide emissions by humans and vehicles. The calculation was then multiplied by the emission factor. This was important in calculating the absorption capacity of total carbon dioxide from the existing greenspace vegetation.

\section{Results and Discussion}

The inhabitants included in the calculations were the resident population in a radius of $400 \mathrm{~m}$ from the existing greenspace. The average population density in the area was found to be equal to 5,759 people/km².

The study determined that the largest number of motor vehicles are in the main road that is connecting to residential areas. The number of 2-wheeled vehicles was found to be more dominant than motor 4-wheeled vehicles in almost all parts of the zone with a small exception.

The following formula can be used to calculate $\mathrm{CO}_{2}$ emission load based on the number of vehicles:

$\mathrm{Q}=\mathrm{Ni} \times$ Fei $\times \mathrm{Ki} \times \mathrm{L}$

where:

$\mathrm{Q}=$ Amount of emissions $\left(\mathrm{CO}_{2} \mathrm{gr} / \mathrm{h}\right)$

$\mathrm{Ni}=$ Number of i-type motor vehicle (vehicle/h)

Fei $=$ Emission factor

$\mathrm{Ki}=\mathrm{i}$-type specific energy consumption (L/100km)

$\mathrm{L}=$ Path length $(\mathrm{km})$

The $\mathrm{CO}_{2}$ emission factor value for motorcycle and car type is about $3,180 \mathrm{~g} / \mathrm{kg}$ of fuel. Specific energy consumption for car vehicle types is $11.79 \mathrm{~L} / 100 \mathrm{~km}$ and motorcycles of $2.66 \mathrm{~L} / 100 \mathrm{~km} .^{5}$
The carbon dioxide produced by human activity is about $0.96 \mathrm{~kg} / \mathrm{day} .{ }^{6}$ Total emissions produced by humans can be calculated using the following formula:

Total emissions by humans $=$ Units of $\mathrm{CO}_{2} \times$ population

The population in the area is observed about 17,547 people. The predicted $\mathrm{CO}_{2}$ emission up to year 2023 was amounted to $3.349 \mathrm{~kg} / \mathrm{h}$.

The absorption capacity of the existing greenspace is done by first inventory the plants located in the planning area. It used data from the Department of Sanitation and Green Open Space in Surabaya and the primary data in the form of field observation. The absorption capacity of each plant obtained from various literatures is calculated using the formula to determine the total absorption for each zone. From the absorption of carbon dioxide, which is known from several literatures it can be calculated by the absorption capacity of each tree according to its type. This calculation of absorption can be done by using the following formula:

Absorption ability tree $=$ absorption capacity $\mathrm{CO}_{2} \mathrm{x}$ number of trees

Furthermore, the absorption capacity of the existing grass area (circa $6 \mathrm{Ha}$ ) in the zone can also be calculated. The absorption of grass vegetation is $2.74 \mathrm{~kg} / \mathrm{Ha} / \mathrm{h}$. Thus, $\mathrm{CO}_{2}$ absorption by the grass is about 6 tonne yearly.

Greenspace design is done to reduce emissions in the planning zones through different types of vegetation so that the emissions can be fully absorbed. It also takes into account the aesthetic as well functional aspect of plants as a sun-absorbing shade.

Human beings are the largest contributor of $\mathrm{CO}_{2}$ emissions in the planning zone, in addition, vegetation for each zone will also be a supporting program where each household consisting of 4 people is required to plant 1 plant so that it will reduce $\mathrm{CO}_{2}$ emissions in the planning area. The selected plant is a mango plant (Mangifera indica) that has an absorptive capacity of $259.8 \mathrm{~g} / \mathrm{h} .^{7}$ This plant is 
selected because it is easy to be cultivated and can be consumed by the people. Therefore, the planning zone needs greenspace with absorption capacity of $11,397 \mathrm{~kg} / \mathrm{h}$.

The existence of the program is expected to help reduce $\mathrm{CO}_{2}$ emissions, which is limited to the available land. In public greenspace planting zig-zag vegetation will provide maximum opportunities for sunlight interception. The arrangement of planting is according to the Ministry of Public Works Regulation number 12 of $2009 .{ }^{8}$ According to this regulation that the distance between vegetation should be 4 meters.

\section{Conclusion}

Based on the above results, it can be concluded that the existing greenspace vegetation can not absorb $\mathrm{CO}_{2}$ emissions from motor vehicles and people. Addition of new vegetation with high capacity of absorption capacity is needed in conjunction with a program of 1 household 1 plant.

\section{Acknowledgement}

The authors wish to thank the Department of Environmental Engineering, Institut Teknologi Sepuluh Nopember (ITS) Surabaya for financial support for this research project under the program of final assignment 2018.

\section{References}

1. Caparros-Midwood, D., Barr, S., \& Dawson, R. (2014). Optimization of Urban Spatial Development Against Multiple Sustainability Objectives and Climate Risks. In Vulnerability, Uncertainty, and Risk (pp. 145-154). Reston, VA: American Society of Civil Engineers. https://doi. org/10.1061/9780784413609.015.

2. Peraturan Menteri Pekerjaan Umum Nomor 5 Tahun 2008

3. Badan Pusat Statistik. 2017. Surabaya dalam Angka 2016. Surabaya: BPS Kota Surabaya.

4. Liu, W., Chen, W., \& Peng, C. 2014. Assessing the effectiveness of green infrastructures on urban flooding reduction: A community scale study. Ecological Modelling, 291, 6-14. https:// doi.org/10.1016/j.ecolmodel.2014.07.012.
5. Badan Pusat Statistik. 2018. Kecamatan Dukuh Pakis dalam Angka 2018 Surabaya: BPS Kota Surabaya.

6. IPCC. 2006. IPCC Guidelines for National Greenhouse Gas Inventories -Workbook (Volume 2). http://www.ipcc.ch

7. Brink, E., Aalders, T., Ádám, D., Feller, R., Henselek, Y., Hoffmann, A., ... Wamsler, C. 2016. Cascades of green: A review of ecosystem-based adaptation in urban areas. Global Environmental Change, 36, 111-123. https://doi.org/10.1016/j. gloenvcha.2015.11.003.

8. Permen PU Nomor 12 Tahun 2009 tentang Pedoman Penyediaan Dan Pemanfaatan Ruang Terbuka Non Hijau Di Wilayah Kota/ Kawasan Perkotaan. 